Article

\title{
Youth Justice, Black Children and Young Men in Liverpool: A Story of Rac(ism), Identity and Contested Spaces
}

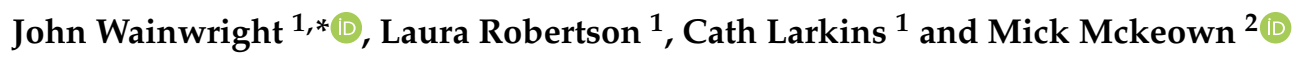 \\ 1 School of Social Work, Care and Community, University of Central Lancashire, Preston PR1 2HE, UK; \\ laurar33@hotmail.co.uk (L.R.); CLarkins@uclan.ac.uk (C.L.) \\ 2 School of Nursing, University of Central Lancashire, Preston PR1 2HE, UK; mmckeown@uclan.ac.uk \\ * Correspondence: jpwainwright@uclan.ac.uk
}

Received: 10 April 2020; Accepted: 28 April 2020; Published: 6 May 2020

\begin{abstract}
This study explores the experiences of the black children and young men that attended a Youth Offending Team (YOT) in Liverpool, a city in the North of England, UK. It focuses on the perspectives of both the YOT practitioners and the black children/young men as they develop working relationships with each other. Through this two-way prism the back children/young men reflect on what is important to them before and after they enter the criminal justice system. Likewise, the YOT practitioners provide their understanding of the key issues in the young people's lives-in particular, how the black children/young men made sense of their lives in Liverpool with a particular identity with place, space, class and race. A genealogy of race/class prism, along with an intersectional and appreciative inquiry methodology, was employed that encouraged the youth justice workers and young black men to explore the strengths and realities of their lives. Focus groups were undertaken with seven YOT practitioners and managers, along with semi-structured interviews with five black children/young men. The methodology focused on points of intersection of power, difference and identity. Findings that emerged from the participants included the experience of racism within the criminal justice system, the community and the wider city, along with the importance of education, employment and relations with the young people's family. A core theme was an identity of black children/young men from a specific region. This intersection was as Scousers, black boys/young men, the contestation over space and their negotiated identity regarding race. The ambivalence and (un)certainty that these identities evoked provide possibilities for youth justice practitioners engaging with young black men involved in serious and repeat offending.
\end{abstract}

Keywords: race; racism; black; young men; Liverpool; space; identity; criminal justice system; intersectional; youth justice

\section{Introduction}

This report provides findings from a study that explored the narratives of youth justice workers ${ }^{1}$ and black boys and young men $^{2}$ as they enter and engage with the youth justice system. Specifically,

1 Practitioners that work in Youth Offending Teams.

2 In England and Wales, the legally recognised age of criminal responsibility is 10. Between the ages of 10 and 17, young people committing a crime can be arrested and processed through the courts but will receive different sentences to adults and if a custodial sentence is warranted, this will be served in a young person's facility. The legal threshold for treatment as an adult is 18 , but $18-25$ year olds have their own custodial facilities. 
it focuses on (i) how youth justice workers, in Liverpool's Youth Offending Team (YOT) ${ }^{3}$, considered and worked with black children/young men and (ii) how black boys and young men understood their previous experiences before their journey into the criminal justice system and when subsequently coming into contact with their youth justice workers in the YOT. Of key interest was how the black children/young men made sense of their lives in the city of Liverpool with a particular identity that resonates strongly with issues of place, space, class and race ${ }^{4}$. To explore these issues, youth justice workers were encouraged to discuss their work with black children and young men through the intersectional lens of race, class and space. The black children/young men were encouraged to do the same from their perspective. Whilst the youth justice workers also discussed black children/young men's offending behaviour, the focus of this study was on developing an understanding of the world the young people had to negotiate, their journey into the system and their everyday lives.

\subsection{Black Young Men and the (UK) Criminal Justice System}

Several studies acknowledge that the experiences of children and young men (between the ages of 10 and 17) of Black, Asian and Minority and Migrant Ethnic heritage (BAMME) who come into contact with the criminal (youth) justice system experience specific disproportionately discriminatory treatment (Wilson 2006; Williams and Clarke 2016; Lammy 2017). Further, some studies suggest that initial contact with the criminal justice system is still as much based on detrimental racial stereotypes held by the police as evidence of offending behaviour (Goldson and Chigwada-Bailey 1999; Apena 2007; Sharp and Atherton 2007; Home Office 2016). Beyond their entry into the youth justice system, such negative perceptions of BAMME children and young people are also substantially influential on their journeys through the system (Mullen et al. 2014; Taylor 2016; Lammy 2017).

BAMME children and young people continually have to negotiate the discrimination they (and their families) experience that extends to wider exclusion from socioeconomic, political and cultural participation in society (Kundnani 2007; Harries 2014). This means that children and young men of BAMME heritage often find themselves in environments, in spaces, where it may be more difficult to not become involved in offending behaviour, or to desist from further offending (Wilson 2006; Youth Justice Board 2010; Allen and Williams 2015; Bramley et al. 2015; Nichols 2017). Whilst there is clear evidence of disproportionate and discriminatory treatment of BAMME children and young men in the criminal justice system, it has been suggested that young black people of BAMME heritage in the England often paradoxically silence race in their representation and understanding of their everyday experience. To be able to cope with racism, BAMME children and young people may deny its personal impact; particularly, as in their everyday lives, rac(ism) as a reality is often diminished by others (Winant 2004; Harries 2012, 2014). Yet, this denial of racism, this silencing of race, contradicts BAMME children and young people's actual experiences. As Harries (2014, p. 5) suggests, race is much more obviously challenging in their lived reality, as 'black bodies are always made visible in predominantly white spaces'.

\subsection{Intersectional and Spatial Exclusion across Liverpool}

This paper explores what this visible exclusion means for black children/young men in the youth justice system using the city of Liverpool as a case study; a city with the longest established black community in the UK (Costello 2001). Importantly, this involves a consideration of how the local youth justice workers respond to this process in their interventions. Although generic terminology

3 Youth Offending Teams (YOTs) are the statutory agency in the UK that work with children and young people to prevent them from offending or desist from this behaviour. There is one such YOT in Liverpool providing a service to children and young people across the city.

4 Race is a contestable term because it is a social construction and does not actually account for biological difference, there being more genetic diversity within rather than between so-called racial groups. However, the term is used in this article with reference to its commonplace association with differentiation and othering. 
such as BAME (without the last M for Migrant), or BAMME are used to represent and name people of colour and/or with a history and heritage of migration, the term black will be used to identify the young men/children in this study. This is because it is arguably the case that black represents the particular, ethnic, political and cultural heritage of people of colour in the city of Liverpool-most of whom are of African, Caribbean and/or mixed white/black African or Caribbean heritage-and, as a signifier, is bound up with certain political perspectives on race. Black is, thus, a term, a name, an identity embedded and embroidered with a history, of racism, struggle and exclusion within the city (Gifford et al. 1989; Zack-Williams 1997; Christian 2008; Brown 2009; Wainwright et al. 2019). Black is also a political totem that is a positive identity for African, Caribbean and some more broadly constituted ethnicities and migrant groups, one that is defiant in its Otherness and resistance to racism (Sivanandan 1985; Singh 2004; Wainwright 2009). This study is focused on black children and young men, with African or Caribbean heritage, because they are the most over-represented group in the criminal justice system and there is a lack of specific research that begins to explore their everyday experiences (Mullen et al. 2014; Lammy 2017).

However, when considering encouraging black children/young men to desist from offending behaviour, it has been suggested that race is but one category that should be considered and a focus on intersectional identities, including gender, masculinity, poverty and social disorganization, needs to be understood, along with the impact of power and privilege in the UK (Calverley 2013; Glynn 2016). This has particular resonance in Liverpool, where issues of race and access to place and space have forged a particular identity for black people (Zack-Williams 1997; Boland 2010). In particular, Glynn posits that the practical implications of taking such an approach to desistance for black people dealt with within the criminal justice system would require 'culturally competent rehabilitative processes' through networks and activities which support their desire to desist and which radically reframe interlocking oppressions of criminal justice processes that render them subordinate (Glynn 2016, p. 24). This may inform an understanding of a lived experience of black children/young men, that, in the face of racism, racialisation of their communities and families, there is often an uncertain, ambiguity portrayed regarding their own identity (Harries 2012, 2014). It has particular relevance to the experience of the black children and young men in Liverpool, where there is an acknowledgement, by some, of the structural and institutional racism embedded within the city, yet the discourse of $\operatorname{rac}($ ism) is denied in the everyday narrative of Scousers, typically defined and unified by class and poverty (Gifford et al. 1989; Boland 2010). This means the intersectional spaces for black young men to articulate their experience of rac(ism) and identity are squeezed to that of ambiguity (Hall 2000; Harries 2014; Joseph-Salisbury 2019).

\subsection{The Place of Liverpool-An Exceptional Northern Town}

The saliency of place in the formation of identity for individuals and communities has long been established (Haesly 2005; Anderson 2006). Liverpool is a particular locus, with a distinct, rebellious 'Scouse' identity that is recognised throughout the UK and in many parts of the world (Belchem 2006; Boland 2008). This is bound up with a distorted negative media portrayal of a city having survived particular economic and social disadvantage and its people, reflecting a mainly working class character, with an alleged propensity to criminal behaviour (Beynon 1984; Taaffe and Mulhearn 1988; Boland 2008). It is worth noting that Liverpool is a quite compact city and, with the River Mersey running south to north, there is only a north, south and east end; in historical, political and social terms, the demarcation between north and south is crucial (Meegan 2003).

When considering Liverpool and the experience of black children and young people, placebased loyalties and identities are distributed at city and local neighbourhood levels. For instance, districts of the city such as Kensington, Toxteth, Dingle or Norris Green all have their own character and demography. Within this nexus of loyalties and contested identities linked to specific areas, or places, is the historical and geographic representation of racialized economic and social relations (Ben-Tovim 1997; Boland 2010). These are manifest in the (aforementioned) long established black 
community of Toxteth, Liverpool $8^{5}$ in particular (Heneghan and Wailey 2015; Hughes 2015; Vathi and Burrell 2020), with a high proportion of black (dual heritage) families, children and young people (Small 1991; Law and Henfrey 1981; Ben-Tovim et al. 1986; Liverpool Black Caucus 1986; Brown 2009; Caballero and Aspinall 2018).

Toxteth, or Liverpool 8, is the one area that the black community predominantly, but not exclusively, reside in and is perceived by those who live in the city and the UK more widely as co-terminous (Lashua 2015). This identification is typically associated with the 1981 riots $^{6}$, and perceived in a negative and pathological sense in the wider area of Merseyside (Gifford et al. 1989; Ben-Tovim 1997). To exacerbate this experience of exclusion, the wider importance of the black community in Liverpool is often denied, such as its contribution to the social, cultural and economic development of the city, including for example the history of the music scene; itself a huge part of the city 'brand'. Indeed, the experience of the Liverpool black community has been demonstrably one of continuous exposure to and struggle against racism and discrimination coupled with effective exclusion from power (Zack-Williams 1997).

The importance of geographies of racism and how these have created segregated patterns of residence and other exclusions are crucial factors in understanding matters of identity with regard to specific Liverpool neighbourhoods such as Liverpool 8 (Small 1991). The black community, thus, possesses a certain ambivalence to the city and Scouse identity, yet is also definitely Scouse with regard to geography and accent, and can adopt and perform a Scouse identity whilst maintaining other heritage, cultural and place attachments, including to Liverpool 8 (Boland 2010). Boland (2010) draws attention to the idea that Liverpool 8 exemplifies a notion of an imagined community, in that any sense of belonging to 'the community' need not depend on knowing all others in the community, rather there is a strong sense of common bond (Anderson 2006; Boland 2010)

This fluidity presents particular opportunities and challenges for black children and young people within the city. Toxteth and Wavertree (the neighbouring ward to Toxteth), it could be argued, provide a safe space: this is enacted in terms of belonging and identity, where residents have been brought up by their (grand) parents to understand that their black relatives have lived there for 'hundreds of years' (Wainwright et al. 2019, p. 8). It is their black community, their space. In a city where divisions are signified through race, class and place, it is a part of the city that can potentially provide a sanctuary from the racism that they may experience, if not even recognise, elsewhere in the city. This affects black children and young people through institutional and epistemic racisms that work out in implicit and explicit ways; worked out in discriminatory geographies, social relations, employment, housing, education and lack of opportunities (Zack-Williams 1997; Boland 2010; McKeown and Wainwright 2019). The place, however, also provides challenges, as being black and belonging in the city is particularly, but not exclusively, associated with Toxteth (Liverpool 8). Which means, for black children and young people, residing, or frequenting other parts of the city, can open up the possibilities of being confronted by others (children and young people) about matters of identity, belonging, and race-typically, and territorially associated with place and space.

It is this context, this backcloth of a myriad of institutional and epistemic racism(s) that excludes black people in the city of Liverpool in a particularly unique and discriminatory way, that provides the rationale to explore the experiences and understandings of black children and young men in their everyday lives, and from the perspective of their YOT practitioners.

5 The district of Toxteth comprises the electoral wards of Granby and Abercromby and is almost co-terminous with the postal area Liverpool 8. Local people and commentators typically use Toxteth and Liverpool 8 interchangeably.

6 The 1981 riots marked a point in Liverpool's history where the black community fought back against racist policing and the social, economic, political and cultural exclusion in the city. See (Frost and Phillips 2011; Gifford et al. 1989; Zack-Williams 1997) amongst others. 


\section{Methodology}

The purpose of this study was to establish what, if any difference, black children and young men experienced through their journey into and through the youth justice system. By exploring this issue through (i) an intersectional methodology that accentuates the strengths and realities of African/Caribbean experience and (ii) a race, class and place prism, both the YOT practitioners and black children/young men discussed everyday realities in ways that made sense to themselves (Crenshaw 2019; Glynn 2016; Wainwright and McKeown 2019).

The methodologies used to undertake this research combine the lenses of appreciative inquiry (Cooperrider 2017), intersectionality (Crenshaw 2019), and the genealogy of rac(sim). Appreciative inquiry comprises a collection of participatory approaches and an ethos respectful of individuals' agency and generativity and seeks to identify personal strengths rather than focus on deficits. Intersectionality provides a prism with which to explore the individual experiences of black children and young men that acknowledges the multi-dimensional nature and fluidity of their identities (Glynn 2016). A genealogy of $\operatorname{rac}($ ism) is concerned with how race is attributed to negative characteristics for black people (and people of colour more generically) and how it can enable a 'multi-textured bricolage' of understandings of these processes of racialisation (Nayak 2006). It is used as a tool of reflexive analysis to enable an understanding of how individuals, YOT practitioners and black children/young men made sense of race and racism (Miles and Brown 2003). Drawing on some of the thinking of appreciative inquiry, part of the focus of the discussion with the YOT practitioners and the black children and young men explored, respectively, the interventions that were most productive and the activities that participants thought they were good and/or skilled at doing. This can provide the opportunity for young people to work with their YOT practitioners to bring about change that is positive in their lives (Hammersley 2002; Reason and Bradbury 2006).

By focusing on the things that mattered to them, discussions were held that centred on a race, class and place pris-one that gave meaning to their world, from their perspective (Boland 2010; Wainwright and Larkins 2020). This was done by asking the black children/young men to talk about their lives-what was important, difficult or what they felt good about. Likewise, YOT practitioners were asked to think and talk about race, community, and offending related to black children/young men and to think about the realities of race and racism for the young people as a primary issue in their lives (Apena 2007; Mullen et al. 2014; Lammy 2017). For this research inquiry, of key interest was how the participants made sense of their world within this city.

Four meetings were held with YOT operational managers to sketch out the parameters of the study which culminated in a focus group with seven practitioners-four of whom were white and three were black (and of dual heritage); two of the white practitioners were managers. Three of this group were women, two black and one white. The focus group took place before the semi-structured interviews with five black children/young men and provided an opportunity for practitioners to think and talk about race and the experience of black children that attended the YOT. The discussions also provided the space for the practitioners to reflect on race more widely, in the community, in the city of Liverpool and, just as pertinently, in their lives and the lives of other black and white children in the community.

Later on, over a period of 12 months, five black boys/young men (two were aged 14, one 16 and two 17) were invited to participate in individual interviews to discuss their lives, their world, their understanding of their biography, identity and community and the offences they had committed. The black boys/young men all resided in Liverpool and were statutorily obliged to attend the YOT as part of the supervision process because of the offences they had committed. They were asked to be interviewed by their YOT practitioner and participated voluntarily, although each interview was accepted by their YOT practitioners as a formal supervision contact. They were of dual (African/Caribbean-white), or black (African/Caribbean) heritage. Importantly, these discussions were more concerned with who they were and what they had thought and experienced about their daily realities. Any discussion regarding 
offences was introduced into the conversation by the black children/young men and not the researcher, as the focus of the interviews was on their journey and reflections on circumstances in the present.

Before the interviews and focus group were undertaken, ethics approval was gained from the University of Central Lancashire and consent forms with detailed and accessible information were provided to all the participants. Information about the research was provided in written form, but also explained at length on several occasions to those that took part. All the participants had the right to withdraw at any time without detriment.

The lead researcher who undertook the interviews with black children and young people as well as the youth justice workers was of dual African/Caribbean and white British heritage. Although he had spent most of his life in the city, he was not born there. This important and not so subtle distinction informed the race/intersectional prism with a dual insider/outsider framework with which to listen, communicate and understand race and place (Merton 1972; Boland 2010; Obasi 2014). The other researchers were a woman of white Scottish heritage, who was involved in all the planning of the project and discussions and initial meetings with the YOT managers; a white woman with expertise concerning participatory practices with children and young people; a white man with a Scouse heritage, with expertise regarding intersectionality of mental health, race and place in Liverpool.

\section{Findings}

The discussions with the youth justice workers and black children/young men explored their understanding of their relationships with their YOTs and their families and their journey that led them into the criminal justice system, identifying some of the issues that were important in the black young people's lives. The discussions articulate the intersections of some of the black children/young people's experiences with those of the youth justice workers and the differences between the two sets of participants are also identified. Commonalities of journeys included an understanding of the importance of their city, and particularly identity, that resonated with both the YOT practitioners and black children/young people. Considerations of family, community identity and racism also resonated with both groups of participants. The findings present the reflections of the youth justice workers followed by those of the black children/young men in each section.

\subsection{In My Liverpool Home}

For the locals, there is something quite unique in this city of Liverpool-no matter what the topic, whatever the subject, the experience or tale to tell, being of and from Liverpool, being born in Liverpool, brings with it particular insights, rights and privileges to claim a unique understanding of the experiences of discrimination, particularly regarding rac(ism), class and sexism. For those born in the city, it is how these identities and divisions are represented and intersect with geography, with the place of Liverpool, that is important. There is a Liverpool worldview. There is pride in the knowledge that their experience, both collectively and as individuals, is unique in its hardship, discrimination, oppression and unfairness (Belchem 2006) despite concerted efforts at rebranding the city (Boland 2010). To a large extent, this is born out through evidence, history and biography (Belchem 2006; Christian 2008).

The participants in this study invariably related to this perceived uniqueness, this particular experience and how it has informed their understanding of the city with its difficult and dubious past when considering race and racism:

you don't see black train drivers or working in the shops ... and saying to black people this is our city. I have been here fifty three years and there are still places I don't go to on my own for the main reason of the colour of my skin and the fact that I don't feel welcome in those communities... If you go into Liverpool One masses of money has been invested in the new shopping area but you won't find ten black shop assistants in the shops. It's like going back to the riots when MST (Merseyside Skills training) and stuff like that were set up to try and give black people employment opportunities. To give black people more opportunities. (youth justice worker-black woman 1) 
Traditionally there is a history of young black people being shunned or unwelcome in town ${ }^{7}$. Don't know how prevalent that is now ... When you go to Manchester it is so diverse. You go to London you see white people, black people, Asian people talking to each other. It doesn't happen here. (youth justice worker-white man 1)

The boundaries that have restricted and discriminated against black people in Liverpool for so long were placed in contrast with another city where a youth justice worker had previously lived:

In London we used to have a diversity forum ... but Haringey where they did it good is that we used to talk to the community. When I went to work in Haringey. I was like an ethnic minority and it made me think. It's like going along and meeting people and going to Seven Sisters and like it's amazing here. Turkish, Congolese, Somali all different shops and stuff like that ... I loved it ... in contrast to my childhood which is north Liverpool ${ }^{8}$ and I don't think I saw a black person 'til I was a teenager ... apart from maybe in town. (youth justice worker-white male 1)

There was universal agreement amongst the youth justice workers that there was still significant discrimination experienced by the black community in Liverpool. However, the experiences of the black children/young men were more nuanced, or ambivalent about the city that they lived in and about race:

I reckon it is getting easier innit. Me being from Chinatown (on the edge of Toxteth). I've got no trouble with anyone ... I don't reckon its hard or nothing being black living in Liverpool. Reckon its easier. (black young man 1)

It may be that the experience of rac(ism) for this young man has been mediated through regular contact with white people, as the majority population in the city, enabling him to negotiate relationships with others not defined by race. Or, perhaps, the group of friends that have been involved in offending behaviour could have been more inclusive in terms of race. Likewise, it could be that any groups once properly formed become less riven with discriminatory attitudes because personal relationships, once established, may mask differences around race:

I live in another part. Not here, Toxteth, but up in Kensington. Some of my mates are white and some black. They've both got my back. (black child/young man 2)

Despite there being a sense of diminished exclusions, for some, relationships with the police, especially in particular areas, remain vexatious:

I don't go into town much ... so don't know what that's like, but not really ... just the police that always get on me. When I am around here or the park [Sefton]. (black child/young man 3)

The black children and young men tended to think about their lives through individual experiences, rather than any sociopolitical overview, or wider contextualisation of their daily lives. They expressed being discriminated against and feeling different in several other settings, but not in their relationships with their friends or (enemies) over race. This may explain how both the views of the youth justice workers and those of the black children/young men may simultaneously reflect an accurate and lived experience. Perhaps this is also due to a difference in political perspective; whereas the youth justice workers-all of whom were from Liverpool—possess a historical and sociological lens through which they experience Liverpool, the black children and young people talk of their biographies in the everyday here and now, the present.

7 'Town' is the local vernacular for the city centre.

8 Toxteth is located in south Liverpool, where the black community resides; north Liverpool has until the last ten years had a predominantly white population. North Liverpool may be geographically not such a long way from Toxteth (3 miles to Anfield, 5 to Norris Green, and 8 to Kirkby), with Liverpool being quite a compact city, yet the psychosocial 'distance' and associated exclusions may be more profoundly felt. 


\section{2. 'They Can't Even Get out of Their Own Area'}

Whilst there was general acknowledgment that the experiences of black children and young people in the city were mediated through rac(ism), there was also an appreciation of the processes whereby intersections of class, identity and resources impacted on the relations and conflict between black and white children/young people (Boland 2010). Again, the lens of the youth justice workers was different to that of the black children/young people. Despite such differences in perspectives, all understood that much of the conflict related to issues of class, race and narrow place affinities:

There are people who have been through the system. I'd like to do research in the Dingle area of the city. That has caused a big massive problem with our own (black) youth, never mind our black kids cannot go and get a job. They can't even get out of their own area ... The Dingle kids are angry with the Toxteth kids as they have a brand new youth club. This is what I am hearing. White kids in the Dingle, they feel as if they are excluded the forgotten generation. To some extent they are, but it goes deeper and deeper ... it goes back to generational poverty. Kids running round all hours and selling drugs. (youth justice worker-black woman 2)

These rivalries may in part mirror the political contestations within the city, where the parochialism of local politics informs competition and envy between different places (wards), undermining a more citywide collectivism (Ben-Tovim 1997; Belchem 2006). This also resonates with another youth justice worker's observations on the importance of geography- that of race, class and place on black children/young people's relations with white children/young people. A contrast is made between the experiences of black children/young people born and brought up in Liverpool 8 (Toxteth) and those children of African heritage finding themselves located in a predominantly white area of the city:

You have the black community in Liverpool 8. Quite generational and you have a kid, like a black kid, whose parents were like from Zimbabwe in Anfield and his parents were in Anfield in terms of what the differences are. What I am trying to say is that you have third, fourth, fifth generation or whatever ... living in Toxteth, got his identity and is quite happy and you may have a kid who Is not happy with that and is excluded from services because of that. (youth justice worker-white male 1)

Reference is made here to the generational embeddedness of rac(ism) and class within the city and the effect this can have on a black child/young person's identity, their life experiences, horizons and opportunities. There is also an acknowledgement of place attachment and affinities linked to positive identity. This is also contrasted with a new generation of African families, children and young people who have been moved by the local housing associations into the north and predominantly white areas of the city. Of particular interest is how these relocations and dislocations can inform individuals' sense of identity and belonging, or not, in the city and whether, or how, $\operatorname{rac}($ ism) is negotiated through these daily lived experiences (Heneghan and Wailey 2015; Hughes 2015; Vathi and Burrell 2020).

Instead of them (children/young people) going round and hating everyone. People think there is a race war going on between the white kids. Because they are all Liverpool 8 kids as well ... it is not $a$ [exclusively] black area at all ... around the Princess [Avenue], [Upper] Parliament [Street], Granby area is black. You go to the other side and it's segregated, and it's always been like that ... But now you've got a new generation of kids growing up and they don't know what their issue is and why they are having big massive wars on the streets as kids. (youth justice worker-black woman 2)

The interconnection and intersection of race and place is thus ingrained in the experience of both black and white communities in the city (Hughes 2015; Vathi and Burrell 2020). The youth justice workers say that this historical context of conflict and territorial 'ownership' of place in particular areas of the city has been passed down to children and young people from previous generations (Wainwright and McKeown 2019; Wainwright et al. 2019). Further, that this, in part, provides the backdrop for 
conflict and confusion regarding black (and white) children and young people's experiences of racism in the city.

The intricacies of local geography also impact directly on the Youth Offending Team service provided to both black and white children in Liverpool:

One of the issues we may touch upon, in terms of the venue. The geography. We cover the whole of Liverpool ... in terms of both gang issues and of young black people feeling comfortable go up the north end. We also get some issues of young white people not wishing to come down here because it is the other end of the city. (youth justice worker-white male 2)

This youth justice worker is pointing out that the YOT office where they work, which is the main point of contact for all children that are statutorily obliged to attend, is in the south area of the city. It is situated close to Toxteth, which makes it problematic for some children to visit, as they have to travel through the other's space or indeed other gangs' purported territory:

I think there are multi layers of this. Traditionally Liverpool has always been north and south. I would consider these two distinct cultures in terms of north end and south end. In turn the history of the black community in terms of long heritage of Liverpool black scouse based in the south end. With the changing demographic of the city, there are various groups who are Eastern European. White and black populations that are going elsewhere in the city and in terms of flux delivering services but what it is like for those young people out there. (youth justice worker-white male 2)

These changing demographics of Liverpool furnish new challenges for youth justice workers and the young people who need to navigate respective spaces and places across the city. However, the challenge for the youth justice workers and the young people is a familiar one for all those practitioners that are providing centralised, or one point of contact, services. Children and young people, black and white, have the challenge of negotiating the space of other's areas that are claimed as their own patch, or territory, with accompanying investments, identity and propriety over that particular space (Neely and Samura 2011; Lashua 2015). This is problematic, as it impedes black and white children from accessing their youth justice workers or making the necessary and statutory contact with their YOT.

This comment is from the same black child/young person who had also claimed he did not experience rac(ism) in his everyday life:

But the fact that I am black and from Toxteth I have got trouble anyway and they think I am from Toxteth and they don't like Toxteth. I've got trouble anyway. (black child/young man 1)

The quote demonstrates an ambivalence (Omi and Winant 2002; Harries 2014) and perhaps a denial of the micro aggressions of racism that black children may use as a survival strategy to cope with its effects (Harries 2012). Despite a certain reluctance on the part of this black young man to attribute racism to his troubles, this reflection directly links disadvantage to the place of Toxteth; and, by implication, identity. Complexities of familial and friendship relations may also be implicated in such uncertainties regarding the micro aggressions of rac(ism) (Harries 2014). Another child/young man highlights some of these, located within the particular racial and social history of Liverpool 8 as a community that has emerged through dual (ethnic) parentage relationships and friendships that cut across ethnic divides:

Black and white kids watch your back... they like me, because I am small and can get on the back of bikes easy. Get away with stuff and know that I am their mate. Yeah. They don't give me no trouble. Not really, got both, you know what I mean? Black and white ... I'm a mix myself. Mum is white and she is fine. Always got my back... yeah, always. (black child/young man 3)

This is in contrast to this child/young man's experience, where conflict is more obviously mediated through the prism of race and place: 
Some of the kids from the area [Liverpool 8] are just looking for it and want to fight white lads... they go across Park Road to fight them ... But those Park Road kids don't care either ... and they are up for it. But some of the black boys here just look for trouble with them. It is not about being black, but they just don't like each other. (black child/young man 4)

This view was also confirmed by another boy, confident in his own physical ability to fight and defend himself and his place in the world:

No, they don't bother me. They would know what they would get. It is just survival out there ... black or white ... if they did, I'd see to them. Yeah, knock'em out. Or stab them ... yeah, with a knife. (black child/young man 5)

This young man's response refers to the intersectionality of negative race stereotypes regarding masculinity, and projecting toughness, hardness in the local vernacular, as part of a survival strategy by (black) Scousers. This may inform some of the negative institutional reactions from the police and a vicious circle regarding black children and young men in the places and spaces of Liverpool.

The youth justice workers and black children/young men articulate that they are both aware of $\operatorname{rac}($ ism), identity and how this is acted out in the lives of young people in the place of Liverpool. However, their understanding of the structural detrimental impact of rac(ism) is mediated through their positioning in the time and place of their biographies. In other words, the youth justice workers, as black and white people born and brought up in Liverpool have a political, social and economic analysis of the ongoing structural discrimination caused through divisions based on rac(ism) in the city (Vathi and Burrell 2020). This is acknowledged by the black children/young men as well, but their everyday lives experience the conflict and division regarding rac(ism) on a micro, individual and group level, with black and white children experiencing some common disadvantages and engaged in both conflict and mutual support (Apena 2007). The complexities reveal matters of identity and identification with space and place, with some of these spaces and places racially segregated, and others more mixed. There is a particular geographic/demographic in the city, and young people identify closely with specific areas, and groups in those areas, rather than making neat affiliations defined singularly by specificities of ethnic identity (Heneghan and Wailey 2015). Importantly, although this is acknowledged on an individual level, it is experienced as one of the many intersectional challenges that the black children experience at different times, places and spaces in the city (Crenshaw 2019; Nayak and Robbins 2018).

\subsection{Community and Family}

The youth justice workers articulated that it was as important to develop effective and ongoing working relationships with the black child/young man's family as it was with the child. The working relationship needed to be predicated on trust, openness and an appreciation that, as Scousers, they were part of the same place, the same community as the children that they engaged with on a daily basis. These soft relational issues are transacted in something of a contradiction of the aforementioned projection of toughness by some of the black young men. This perhaps suggests another understanding of their ambivalence and even a psychosocial dissonance between such projected 'hard man' identities alongside vulnerability as children, with implications for engagement and desistence work:

Identity and self-esteem. As a white worker how you engage with black youth which is very important. I would have to meet black families and be invited into the house ... made welcome. Engaging with the kids fifteen/sixteen, out of school, poor, lived in poverty, that sort of thing. Having a conversation with the Criminal Justice System. A lot of the sentences. Having a conversation about breaching their order. I like giving them information, which I think empowers them try not to exclude them from the conversation. (youth justice worker-white male 3)

Developing and sustaining these relationships with the young person's family is undermined by the placement of black (and white) children in prisons that are a long distance from their families: 
Now somebody down in London about seven years ago went 'hold on let's ship these kids all over the place.' And kids are being placed as far away as possible from home. (youth justice worker-white male 2)

If you look at the younger kids, that may go to secure training centres. The closest one is Rainsbrook. We have two in Oakbrook. If you drop down a level to the very youngest, they are in Barton Moss in Manchester. So the shrinkage of the estate has had a massive impact on the young people and their families. I think this needs to be looked at in terms of where are young people being placed and why. The fact may be various vulnerabilities because of the risk factors involved. (youth justice worker-white male 3)

Along with the absurdity of placing children in prisons a long distance away from their families and the detrimental effect it will have on them, there is also the potential for potentiating new conflicts relating to place identity:

Our kids were being placed in Lancaster Farms in the first place and we could effectively drive past Hindley (closer to Liverpool) and we were shipping kids up to Lancaster Farms. Then when we changed the age range it then had an established group of our young people in Hindley. There were groups of young people and Scousers in Hindley and segregating them to be able to keep the establishment safe. (youth justice worker-white male 2)

A lot of poverty stricken families that can't afford to go away to see the kids. I always say that when they are away (in prison). When it comes down to it. It comes down to the black or the white side. And half the kids are not even racist, they just automatically choose the sides. (youth justice worker-black woman 2)

The black children/young people all expressed the emotional and psychological importance of their family in their journey and their daily lives, at times making connections to a sense of belonging to their local black community in Liverpool 8:

I think you know (the researcher) my uncles. (Two names are mentioned that I acknowledge). They are from around here, the area. All of my family are from here. It is sick. I like having them around me, they look out for me if any kids want trouble. (black child/young man 4)

Family ties are central to their experience, and these also relate to important issues of employment prospects and the value of YOT interventions:

My Dad lives here, but my Mum lives in Manchester. Am living here in the area at the moment, but I want to get back to Manchester and get a job. Earn some money. This Skill Mill ${ }^{9}$ project has helped. (black child/young man 2)

The importance of the emotional and practical love and support of family is poignantly articulated by this black young man. At different times in his life, family issues and loyalties have influenced his conduct, leading to him being dragged out of mainstream school and into the criminal justice system (Larkins 2019):

I enjoyed secondary school until year 8 or 9 and then my nan got diagnosed with breast cancer that was affecting my behaviour. Someone said something about my mum when I was in Year 10. My mum was still alive. It got me angry so I had a fight with him. As I was having a fight with him the teacher's like grabbed my bag. But didn't realise it was the teacher so I spun round and elbowed him and just shit myself and ran off. Got home and never went back to school again. (black child/young man 1)

9 The Skill Mill is a project run by the YOT that provides opportunities for young people to earn money through developing core skills for employment. 
Subsequently, things deteriorated for this young person, affected in part by the pain of more family loss:

After my mum passed. I was living on my own and my brother had just had a baby. So it was just me and my dog in the house and my mate was like we need to make some money so we decided to go to Scarborough selling class A. Got up there and got nicked. We was in the cell for like $24 \mathrm{~h}$ waiting to get charged. We got charged with conspiracy for class A cocaine and heroin. My mate got remanded because he had a long record. I got released on bail and got put on tag ... And I was in the courts trying to find a bail address and no one was answering the phone. So I was shitting myself thinking I was going to jail and then they told me that my mate's mum will take me in and that I could go there ... They grant me bail. Put me back on the train and then have lived there (Dingle) from then on. (black child/young man 1)

This narrative illustrates how the passing of the two most important people in the black young man's life contributed to a downward spiral. His emotional connection to his nan and his mum, and their tragic early loss, compounded his journey from a stable upbringing with support and empathy to more challenging experiences in the criminal justice system.

There is a contrast between the youth justice workers' and black children/young man's mutual appreciation of a central role for family in providing the necessary support to navigate their journey through the difficult periods in their lives, and a perceived absence of understanding or empathy from (some) individuals, policies and protocols in the criminal justice system (Larkins 2019). This is not to justify behaviours that may have led to the black children being excluded from the education system but, rather, to contextualise and mitigate some of their behaviours.

\subsection{Education and Hobbies}

The youth justice workers and the young people shared an understanding regarding the importance of learning and recreational activities for thriving. Most of the young people enjoyed their own talents, recognising what they were good at and how it made them feel. This was set in contrast to the negative experiences of being excluded from school or getting into trouble with the police:

The bigger picture talking about young people. You have to educate them or give them the strength to get on with that, but sometimes getting into Liverpool One [employment] and they are not getting interviews for it and they need to be challenged. To think about jobs and to train for them. Also, how they are perceived in certain schools. My daughter came home last week. The first time she had been called a N in school I had to explain to her where the name came from ... where does that come from?. (youth justice worker-black woman 2)

By providing a context of the challenge of racism that all black children/young people experience in the education system, this youth justice worker articulates a clear binary of opportunity versus discrimination that young people often come up against. Further, through referencing her own daughter's experience, outside of the criminal justice system, a clear example is provided that illustrates the everyday experience of racism that black children/young people face in their everyday lives; in school, in work and in the city (Wright 2010; Heneghan and Wailey 2015)

For me it is how you give them strength and the knowledge to combat racism, sometimes it is down to education, sometimes they don't know their own background, where they come from. The young people I have worked with at the moment. I have done prevention, I have done intervention and this is a totally different way of working now because it is more on the employment side of things ... But then the way I work with any young person is that you see me as I am ... Because look at the size of me. $6 \mathrm{ft} 2 \mathrm{in}$, mixed race. I try to install that ... even black or white. You are who you are and be proud of it. (youth justice worker-black male 1) 
Autobiographical narratives of experiences of, and resistance to, $\mathrm{rac}(\mathrm{ism})$ in the education system and more broadly in the city were stressed by all the youth justice workers. In particular, they stressed instilling a pride in their heritage of colour, of being black or of dual heritage, in black children/young men. Yet, there was also a conviction that racism, as and of itself, is never an excuse or mitigation for offending behaviour:

What are they going to tell us? That they felt discriminated because they were stopped and searched by the police? Well we know that. That they had to go to prison for selling drugs? Well you know that, that was your offence, that is what the path has ended up going to Jail. So it goes back to education for me. Exclusion from education. The whole family or whatever, so racism is fine, but they have to accept they did it. (youth justice worker-black woman 2)

The fine balance (Mistry 1996) between the youth justice workers' understanding of the structural and critical importance of education, or employment and the obstacles of racism, is placed within the context of rights and responsibilities and collides with the formal expectations of professional roles (Larkins and Wainwright 2020). In other words, irrespective of racism, black children/young people need to learn that this is not an excuse, a panacea for offending; a figurative 'get out of jail card'.

With the exception of one black young person, an awareness of the enjoyment and fulfilment they gained undertaking hobbies and demonstrating an ability at something that they were good at was universally appreciated:

I play football, yeah and am good at it ... I used to play for Everton under 13s, and also in Toxteth. I play up front cos I am fast and enjoy beating players and scoring. I have stopped now, but should have kept going ... I smoke too much stuff now, so can't be bothered. But I liked doing that ... the kids I hang around with now ... it's different, been about [robbing] cars and selling [drugs] and stuff like that ... but, yeah, you are right. I need to get my act together start playing again. (black child/young man 4)

This sense of fulfilment and achievement was echoed by another:

Box and fight for charity and raised about $£ 800$ for charity. I box at Everton Ridge. It's ok because it is a way to take out my frustration and that... It's good though because I have been raising money for cancer research. Because it is close to my heart. Because I lost my mum to cancer about two years ago. It's all mad innnit ... I'm a middle weight. I work for the Skill Mill in here. Which is like a social enterprise thing and I work for a nightclub in town. Doing promoting the empire... The Skill Mill is good though, it's all manual labour so you have to be fit. All the jobs, you could be doing flagging, the next day you could be doing tree felling, then painting. Jack of all trades. It's easy though. Good money. Earn about two hundred a week so I can't complain. I've learned a few things off of it. They get your qualifications so you can progress after this job. (black child/young man 1)

The value and pride in this young man's boxing is evident throughout his interview and there is a demonstrable sense of achievement because of his success in the sport. The YOT practitioners have skilfully built on his sporting achievement and integrated it into his intervention programme and work experience through the 'Skill Mill'. Through building a relationship with the young men, understanding their biographies and journey into offending and subsequently the YOT, they have provided an incentive, a sense of purpose to their intervention with the black young men. Ultimately, this results in a degree of vicarious pleasure in the young men's work (McKeown et al. 2014). 


\subsection{You ${ }^{10}$ All Feel the Police Have Picked on You}

There was a demonstrable commitment from all the youth justice workers to enhancing the lives of the children and young people that they worked with on a daily basis. All the youth justice workers had an appreciation that some of the challenges and barriers that black children and young people experienced were different to white children, because of rac(ism). However, it was important for the youth justice worker to challenge the young people about their offending behaviour and encourage them to take responsibility for their actions. Yet, there was also a focus on working with the black children/young people to look at the circumstances that they experienced in their lives; the impediments to changing their behaviour, the challenges that provided them with opportunities to offend and the strategies they need to adopt to desist from these behaviours:

From the London boroughs a group of young people were at Sefton Park. They were known as the London boys. They were involved in robberies of bikes, we were getting young people who were placed up here from London placed all around the city. This caused tension with some of our own local young people. (youth justice worker-white male 2)

The theme of the topic is the police. Like you all feel the police have picked on you... The two young men that I am working with it is about being straight with them ... Half of the kids we work with are in custody. (youth justice worker-white male 1)

There is an acknowledgement that the world the black children/young men have to negotiate is even more complicated and challenging than, perhaps, it ever has been before. Issues of offending, territory and space, rival gangs with different geographic identities, albeit also often black children, all trying to negotiate and assert their own space. Indeed, such complexities can cause problems for the some of the YOT practitioners:

It is hard because you are always behind the curve as a white worker. You are not always up to date ... with what's happening. You don't know ... I was speaking to someone the other day and they said that they put an application in, but they did not want to use their address because it was Liverpool 8 because this would damage their chances of getting a job. (Youth justice worker-white male 2)

The youth justice workers all identified that they were from the place of Liverpool and understood their own position of class and race when trying to develop working relationships with young people. The black children/young people generally experienced the police as unhelpful but could make distinctions between particular officers, with some individuals seeming to have personal grudges against them:

I was in Sefton park with my mates. We were just hanging about on bikes and that ... having a laugh, but not doing nothing. Then this base turns up, there was no trouble, one police accused me and another kid having stuff on us ... yeah drugs ... but we told them we had nothing on us ... so we was arguing with them ... and we end up being pulled, put in the back of a base ... spent all night in the cells ... some just have it in for you ... but, some are ok. (black child/young person 2)

Another young person talked about how they felt they were being watched, spied on with surveillance cameras:

They have put a camera on a lamp post right by where I live, by my house. They [the police] are spying on me, always looking to pull me for anything. Whenever there is any kid on a bike riding around, they always come to my house saying that I have done it just because I am small. But [often] it's not me. (black child/young person 3)

10 In scouse, 'you' serves to refer to self (one) or others-in the latter case, spoken as 'youse'. 
The skill and commitment of the youth justice workers in this team is evident in their ability to strike a balance between developing working relationships with the black young people alongside addressing the circumstances that bring them into the criminal justice system-whether it is their (offending) behaviour, peer group, the police, or rac(ism) - all of these factors being bound up with matters of place and space.

\section{Discussion}

Whilst utilising methodologies of appreciative enquiry and intersectionality, the central focus was the genealogy of race, racism and ethnicity (Sivanandan 1985; Solomos 1996). Although it is widely acknowledged that race, as such, is socially constructed, a figment of our imagination (Malik 1996; Miles and Brown 2003; Goldberg 2009) as a signifier of difference, race still dominates our lives (Miles and Brown 2003). By acknowledging the genealogy of race, the somatic and phenotypic differences amongst peoples' ethnicities, cultures and communities, we can understand how such difference is racialized (Hill-Collins 2006; Goldberg 2009). Understanding the conflation of physical markers, skin complexion, ethnicity and culture and (some) communities into reified and ossified races provides a context in which power can be abused and exploited, and racism can flourish (Miles and Brown 2003; Goldberg 2009). As a backcloth for discrimination and unfair distribution of disadvantage in the UK, this is the everyday reality for black children and young people in Liverpool (Boland 2010).

\subsection{The Place of Liverpool, the Space of Toxteth}

The social, economic and political history of Liverpool informed the everyday lives of youth justice workers, primarily as they were born and brought up in the city. The worldview of a city separate and different from other Metropolitan cities in the UK informed their understanding of their own biographies, their journeys and, in turn, their politics and their values (Heneghan and Wailey 2015; Hughes 2015), all of this being influential within the framework of working within a YOT, servicing the wider criminal justice system against a backcloth of a city divided by class and, importantly, by rac(ism). Young people's biographies were similarly redolent of poverty and racism in this city, which was for them defined by boundaries that divided the place of Liverpool into spaces that were variously permissible or prohibited to occupy or traverse (Hughes 2015).

Many of the youth justice workers and the young black men shared residence within the places acknowledged as representative of the Liverpool black community, and the YOT was also based there (Boland 2010). This is the place often interchangeably referred to as Toxteth or Liverpool 8, though the precise boundaries are not completely coterminous. These places that the black community reside in and those that the broader white population inhabit were palpably differentiated, with boundaries marked by notable roads, streets and post codes. These boundaries demarcated spaces for the black community that were contested through shared living space at the edges, or saw regular conflict through physical confrontations.

Park Road, on one such boundary dividing Dingle and Toxteth (although both within Liverpool 8), was seen as a key signifier for this contested and conflictual space. However, the cause of this conflict was racism. For most of the youth justice workers that participated in the focus groups, both white and black, there was a clear recognition, acknowledgment, and, for several of them, a lived biography of a city divided by racism, experienced through their childhood and remaining evident in adulthood in the present day (Gifford et al. 1989; Christian 2008). A city of north and south, where the north was populated mainly by the white community and a specific part of the south (Toxteth/Liverpool 8 and surrounding areas) where the black community resided. This experience, this worldview, informs their work with the black and white children and young men that attend the YOT (Boland 2010; Hughes 2015). There is political and social empathy for the world these children live in, because of the intertangling of racism, poverty, and conflict across the city as a whole and particularly touching the lives of the black community of Liverpool 8 (Wainwright et al. 2019) 
The youth justice workers' experiences suggest to them that, in many ways, very little has changed with regard to the social, economic and political prospects for the children and young people that visit the YOT (Gifford et al. 1989; Ben-Tovim et al. 1986 (Ben-Tovim et al. 1986). The YOT office sits on a racialized boundary that symbolically questions black and white children's legitimacy to enter into this liminal, contested space (Boland 2010; Vathi and Burrell 2020). These contestations also reflect the broader marking out of place-based affinities and identities aligned to proprietary claims on territory revealed in the narratives of the participants in this study, with race and racism never far removed, if not always immediately recognised (Boland 2010).

Thus, experiences of conflict related to place and space were also articulated by the black children and young men, but in a more ambivalent way. As Harries $(2012,2014$, p. 6) puts it, obliviousness to, or denial of, micro racisms may combine with a de-politicised, or different, way of understanding experiences to minimise recognition of race or racism as a primary factor. For the young people in this study, being black amongst their peers did not feel like the most important signifier of their everyday experience. Having black and white peers-both of whom were comfortable in the presence of ethnic, and to a lesser extent, cultural difference-perhaps within a context in which respect is exchanged in relation to alternative currencies of bravado, hardness and offending behaviour all served to minimise race as an acknowledged force.

Some of the black young men had one white parent, which is not uncommon, as dual heritage families constitute a significant proportion of the black population in Liverpool (Small 1991; Brown 2009). There has also been a gradual movement, over the last two decades, of the black population from Liverpool 8 to neighbouring areas, which has blurred the racialized boundaries of some spaces. This was suggested by one black young person who talked about his family, friends and experiences in the neighbouring place and space of Kensington. Other black families, particularly those of African heritage, and recently settled migrants were often placed in the north of the city, places such as Fazakerly, Norris Green and Anfield, previously notable for white working class homogeneity. This changing demography has informed black and white young people's experiences of ethnic and cultural difference and each other (Vathi and Burrell 2020). However, both the youth justice workers and the black young people shared the view that conflict and contested spaces persist, crystallised at racialized boundaries.

The youth justice workers had a clear social and political understanding, attributing the cause of these contested spaces to racism, as a historical legacy and ongoing problem in the city. Whilst the black children and young men lived this contestation, there was a reluctance to name rac(isms) as a distinct causative factor (Harries 2012). Yet, for all who contributed to this study, the place of Liverpool and spaces in between the boundaries, the demarcation lines, are contours of rac(ism) marked by history, struggle, conflict, blood and (un)belonging (Christian 2008; Boland 2010; Frost and Phillips 2011).

\section{2. (Un)Belonging in the Place Where You Were Born}

The youth justice workers and the black young people located their experiences of Liverpool within a frame of reference that explored their experiences about their family. The black community has a history of dual heritage families, many of these originating from West African seafarers arriving in Liverpool and marrying local white women (Small 1991). These relationships were established against a backcloth of racist hostility from most of the local white population in Liverpool (Christian 2008). Some, but not all, of the black youth justice workers were of dual heritage and made reference to their (grand)parents' struggles and conflicts against this racism. Such personal heritage informs their understanding of their everyday experiences of the city where they were born (Heneghan and Wailey 2015; Hughes 2015). Their city, where, in many ways, because of the acknowledged contestations of place and spaces, they are able to forge empathy with the very young people that they work with every day in the YOT. They are from families similar in ethnicity, cultural and class background to these black young people. In the same way, the white workers that participated in the focus groups, on the whole, demonstrated an understanding of the dual heritage, heterogeneous, composition of the local black community and history and contemporary struggles predicated on racism. 
It is these understandings of the local familial and community context in Liverpool that enable the youth justice workers to establish, on the whole, positive, empathic working relationships with the black young people who attend their service. As black workers, when thinking about their black children, they are insiders (Obasi 2014; Wainwright and Larkins 2020). As white workers, they are outsiders. However, both have empathic understanding (Merton 1972). The black youth justice workers are insiders because they, their (grand) parents, and their children have lived the lives, trod the same spaces, the same streets, as the black young people that attend the YOT. Yet, the white workers, as outsiders (Obasi 2014, 2017), seemed to recognise that whiteness, within the city, can access some privilege to the spaces that can be occupied without feelings of alienation, rejection, or experiences of unsolicited conflict (Bonnett 1997). They can, in other words, empathise with the sense of unwantedness (Merton 1972). As youth justice workers, born in the city, they understand the experience of black children, young people in the local community as not being wanted and not belonging; that black children/young people and the black community experience a sense of (un)belonging-being born in the city, only knowing this city as their home, but never feeling quite like that this is their home (Frost and Phillips 2011; Vathi and Burrell 2020).

A stark example of this spatial racism is the experience of black people feeling excluded (of not being wanted, not belonging) from the main shopping centre, Liverpool One, acknowledged clearly by the youth justice workers. Most of the black young people (with one notable exception), although less definitive or certain of their lack of motivation or interest in frequenting the city centre, still seemed less enthusiastic. The paradox of black young people coming from families with, in many instances, generations of heritage of being born in the city, being Scousers, black Scousers, yet not feeling wanted, is something that the black (and white) youth justice workers understood, albeit in different ways. (Un)belonging as black young people is the world, the terrain, the place and space that they have to negotiate (Hughes 2015; Christensen 2017; Vathi and Burrell 2020).

Youth justice workers in the focus group understood this and worked to develop relationships with the black children and young people (and their families) that acknowledged this experience of having a black (often dual heritage) identity and being part of a community from which they felt excluded because of racism and racism alone-being outsiders in the place they were born (Frost and Phillips 2011). This insight and the skills demonstrated by the youth justice workers were key to affecting good working relationships with the black young people and provided opportunities for positive outcomes regarding desisting from offending.

\subsection{Community and Reparation}

The practice in youth justice of building children and young people's skills and confidence by encouraging them to participate in hobbies or activities is well documented (Larkins and Wainwright 2014; Larkins 2016). Appreciative, strengths-based interventions encourage children and young people to explore those activities or hobbies that they enjoy or are good at (Cooperrider 2017). It was evident that, where possible, particularly with the older black young people, the youth justice workers supported this. For example, those of the age of sixteen and over were encouraged to engage in employed activity through a variety of work in their 'Skill Mill'. Further, the two young black men in this study who had participated in the Skill Mill articulated that they found the experience rewarding and fulfilling. This was not least because they were able to earn money legitimately, in contrast to the risk taking and consequences involved in making it from offence-related activities.

These responses and the good practice developed by the youth justice workers involved in the Skill Mill project chimes with national evidence that enhancing and encouraging the skills of children and young people, and demonstrating that there can be a legitimate financial reward, can be a tangible path to them desisting from further offending (McNeill and Maruna 2008; Lammy 2017). Likewise, those black young people that had to engage in reparatory community work expressed a sense of humiliation and embarrassment if they were seen by the public clearing parks and picking up litter, which they felt were activities designed to diminish them (Larkins and Wainwright 2014). The youth 
justice worker leading this project was a black man (of dual heritage) and whether this was by design, or luck, the black young men were able to relate to him because of his identity as an African/Caribbean positive role model (Wainwright and Larkins 2020). Likewise, this youth justice worker emphasised that as someone born in Liverpool, as a Scouser, he could relate to white young men as well in this role.

The importance of being involved in a pastime that the black young men enjoyed, and were skilled at, was unanimously acknowledged. For two participants, there was demonstrable pleasure in being involved in sports that gave something back to the community (McKeown et al. 2014). In particular, one black young man was keen to use his boxing skills to contribute towards a cancer charity, stemming from this having affected his family in such a difficult way. Another felt that because he was good at football and enjoyed it so much that when he used to play for his local team in Toxteth he was contributing to and enjoying being an active and positive contributor to the local community.

The youth justice workers provided a significant caveat to the positive work that was undertaken with the black children and young men-for this study, they identified those that were by definition more cooperative and positive about their relationship with their youth justice workers, the YOT and the community in general.

There was a strong recognition amongst the youth justice workers that to be responsible citizens, the children and young people need to acknowledgement their offending behaviour (Larkins and Wainwright 2020). Further, that offending behaviour that involved county lines, knife crime, and gang-related activity still took up significant part of their work (Palmer 2009). This work was much more challenging for the youth justice workers and they found it difficult to get children/young people to desist from this serious offending (Calverley 2013). Whilst rac(sim) provided the context for the spaces that black young men often occupied, it was not viewed as a mitigating factor for their offending behaviour.

However, the black children and young men, with one or two exceptions, felt that the spaces they occupied were targeted by the police. Whilst they had acknowledged they had committed offences, they felt policing tactics often exacerbated the situation by identifying, pursuing and arresting them, whether or not they had done anything wrong. Their ambivalence regarding rac(ism) as an everyday experience was also articulated in their relationship with the police, where they felt that they were being targeted because they were known to them, or they were seen as part of a gang, rather than because they were black. This understanding of their situation was in complete contrast to the youth justice workers' view, where place, race, class and identity were all taken into account in a more nuanced appreciation of the relationship between social circumstances, offending and the police.

\section{Limitations}

This was a small-scale qualitative study that involved relatively small numbers of participants. As always with such inquiry, claims for generalisability are limited. That said, once the particularities of any place are acknowledged, notions of place affinity and territoriality in the everyday lives of young people caught up in the criminal justice system appear to have a degree of commonplace salience. Whilst the focus on everyday matters has furnished rich understanding of the influence of matters of race, class, place and space in the participants' lives and work, a deeper understanding of individual young persons' offending and engagement with wider criminal justice institutions may have been neglected. Moreover, there is scope to further investigate the sense that race is minimised within the tight social circles within which the young people move and the tensions between awareness of intersectional disadvantage in the lifeworld of all participants and the system in which it is imperative that young people embrace personal responsibility. Future study can potentially explore such issues in greater depth.

\section{Conclusions}

The biographies and the journeys of the youth justice workers and black children and young men speak of a city with a long history of division. In many ways, Liverpool sits separate from the rest 
of the UK, marked by an edgy, rebellious and oppositional identity grounded in class, politics and geography. However, because of local histories of division also based on space, class and race, various demarcations exist-north and south, black and white, evidenced through struggles against racism that have endured for hundreds of years (Christian 2008; Zack-Williams 1997; Brown 2009)—including a diversely constituted black community surrounded by (mostly) a hostile white community. The places and spaces of Liverpool 8 that were, and still are, encouraged for black people, and black children, to enter exist in juxtaposition with those places and spaces where this is discouraged, with symbolic and actual conflict transacted at the boundaries. In many ways, the contested spaces, the obscured places, that black children and young people now find themselves in have their origins of the legacy of the struggles against racism from the early black seafarers. Yet, in other ways, the sands have shifted, ever so slightly, where new migrants have arrived and been forcibly placed in the north and the south, surrounded by white racism and institutionalised hostility.

For black children and young people, and the youth justice workers in Liverpool's YOT that strive with them, there is this sense, this burden of history, of a city with a past imbued in racism, and a present that still subtly and brutally refers to this past. It is open to conjecture whether the blurring of self/other distinctions between this group of workers and their young people that they work with is both a positive force for empathic and effective support, but might also represent a source of alienation for the staff as they access insights into the systematic and racialised disadvantage faced by many of the young people caught up in the criminal justice system. However, they realise how their own employment constitutes another part of the self-same system. Yet, for these workers, the historical record is not an excuse for behaviour in the present, for offending, even if this has the appearance of fighting against the vicissitudes of lives emerging in such a challenging context. For the YOT practitioners, the young people are offered a chance to change, to strive and carve out a new identity: one that focuses on responsibility, challenging and acknowledging offending behaviours and drawing strength from this history of struggle. Thus, the legacy sought by these practitioners is to establish a willingness within black young people to be active citizens, with a positive identity, equally attached to the place and space that they must feel is their own, which is their home.

In sum, the YOT practitioners understand the social, political and cultural history of the city and the everyday lives of the black children/young men. To a significant degree, this informed how the YOT practitioners endeavoured to engage with them. For the black young people, their lives appear imbued with an ambivalence towards race whilst, paradoxically, they are often embroiled in conflicts and contestation over spaces that connect with race and racism. Key conflicts are manifested in their interaction with the police, their peers and rival individuals and gangs. Their relations within their communities, their families and their peers were central to their experiences of both offending and desisting from offending. Their daily experiences, the offending that they were involved in, become caught up in and take place within this complex milieu. Arguably, it is learning from the mutual experiences of these young people and their YOT practitioners that new interventions can be developed.

Author Contributions: Conceptualization, J.W., L.R. and C.L.; methodology, J.W., C.L. and L.R.; validation, J.W. and L.R.; formal analysis, J.W., L.R., C.L. and M.M.; Investigation J.W., L.R.; writing-original draft preparation, J.W., L.R. and M.M.; writing-review and editing, J.W., L.R., C.L. and M.M. All authors have read and agreed to the published version of the manuscript.

Funding: This research received no external funding.

Acknowledgments: We would like to thank the five young men who were interviewed and the youth justice staff who took part in the focus group for this research. We would also like to thank the managers and staff that facilitated the interviews with the black young men.

Conflicts of Interest: There is no conflict of interest. 


\section{References}

Allen, Paul, and Patrick Williams. 2015. We Tell You Peer Based Community Research Interim Findings for Young Black Men's Perspectives on Mental Health. Available online: http://42ndstreet.org.uk/wordpress/ wp-content/uploads/2016/06/We-Tell-You-Interim-Report-November-2015-Final-Version.pdf (accessed on 9 December 2019).

Anderson, Benedict. 2006. Imagined Communities. London: Verso.

Apena, Feyishola. 2007. Being Black and in Trouble: The Role of Self-perception in the Offending Behaviour of Black Youth. Youth Justice 7: 211-28. [CrossRef]

Belchem, John. 2006. Merseypride: Essays in Liverpool Exceptionalism. Oxford: Oxford University Press.

Ben-Tovim, Gideon. 1997. Why "Positive Action" is Politically Correct. In The Politics of Multiculturalism in the New Europe. Racism Identity and Community. Edited by Tariq Modood and Werbner Pnina. London: Zed Books, Chapter 11, pp. 209-23.

Ben-Tovim, Gideon, John Gabriel, Ian Law, and Kathleen Stredder. 1986. The Local Politics of Race. London: MacmMillan.

Beynon, Huw. 1984. Working for Ford. Harmondsworth: Penguin.

Boland, Philip. 2008. The construction of images of people and place: Labelling Liverpool and stereotyping Scousers'. Cities 25: 355-69. [CrossRef]

Boland, Philip. 2010. Sonic geography, place and race in the formation of local identity: Liverpool and Scousers. Geografiska Annaler: Series B, Human Geography 9: 1-22. [CrossRef]

Bonnett, Alastair. 1997. Geography, 'race' and Whiteness: invisible traditions and current challenges. Area 29: 193-99. [CrossRef]

Bramley, Glen, Suzanne Fitzpatrick, Jenny Edwards, David Ford, Sarah Johnsen, Filip Sosenko, and David Watkins. 2015. Hard Edges Mapping Severe and Multiple Disadvantage. Available online: www.lankellychase.org.uk (accessed on 4 December 2019).

Brown, Jacqueline Nassy. 2009. Dropping Anchor, Setting Sail: Geographies of Race in Black Liverpool. Princeton: Princeton University Press.

Caballero, Chamion, and Peter J. Aspinall, eds. 2018. Mixed Race Communities and Social Stability. In Mixed Race Britain in the Twentieth Century. London: Palgrave Macmillan, pp. 53-85.

Calverley, Adam. 2013. Cultures of Desistance: Rehabiliation, Reintegration and Ethnic Minorities. Oxon: Routledge.

Christensen, Ann-Dorte. 2017. Belonging and Unbelonging from an Intersectional Perspective. Gender, Technology and Development 13: 21-41. [CrossRef]

Christian, Mark. 2008. The Fletcher Report 1930: A Historical Case Study of Contested Black Mixed Heritage Britishness. Journal of Historical Sociology 21: 213-41. [CrossRef]

Cooperrider, David. 2017. The gift of new eyes: Personal reflections after 30 years of appreciative inquiry in organizational life. In Research in Organizational Change and Development. Edited by Abraham (Rami) Shani and Debra Noumair. Bingley: Emerald Publishing Ltd., pp. 81-142.

Costello, Ray. 2001. Black Liverpool: The Early History of Britain's Oldest Black Community 1730-1918. Liverpool: Picton Press.

Crenshaw, Kimberle. 2019. On Intersectionality: Essential Writings. New York: New Press.

Frost, Diane, and Richard Phillips, eds. 2011. Liverpool '81: Remembering the Toxteth Riots. Liverpool: Liverpool University Press.

Gifford, Tony, Wally Brown, and Ruth Bundey. 1989. Loosen the Shackles. London: Karia Press.

Glynn, Martin. 2016. Towards an intersectional model of desistance for Black offenders. Safer Communities 15: 24-32. [CrossRef]

Goldberg, David Theo. 2009. The Threat of Race: Reflections on Racial Neoliberalism. Malden: Wiley-Blackwell.

Goldson, Barry, and Ruth Chigwada-Bailey. 1999. (What) justice for Black children and young people. In Youth Justice; Contemporary Policy an'd Practice. Edited by Barner Goldson. Aldershot: Ashgate, pp. 51-74.

Haesly, Richard. 2005. Making the "Imagined Community" Real: A Critical Reconsideration of Benedict Andeson's Concept of imagined Communities. Paper presented at International Studies Association Conference, Honolulu, HI, USA, March 1-5.

Hall, Stuart. 2000. The multicultural question. In Un/settled Multiculturalisms. Edited by Barner Hesse. London: Zed Books, pp. 209-41. 
Hammersley, Martin. 2002. Educational Research Policy Making and Practice. London: Sage.

Harries, Bethan. 2012. Talking Race in Everyday Spaces of the City. Manchester: University of Manchester.

Harries, Bethan. 2014. We need to talk about race. Sociology 48: 1107-22. [CrossRef]

Heneghan, Madeline, and Tony Wailey, eds. 2015. Introduction. In What's Your Granby Story? Liverpool: Writing on the Wall, pp. 1-11.

Hill-Collins, Patricia. 2006. Black Sexual Politics: African Americans, Gender and the New Racism. Routledge: New York.

Home Office. 2016. Police Powers and Procedures, England and Wales, Year Ending 31 March 2016. Available online: https:/www.gov.uk/government/uploads/system/uploads/attachment_data/file/562977/police-powersprocedures-hosb1516.pdf (accessed on 2 October 2017).

Hughes, R. 2015. The Bollards of Liverpool 8. A Sense of Place. Available online: https://asenseofplace.com/2015/ 04/25/the-bollards-of-liverpool-8-2/ (accessed on 1 April 2020).

Joseph-Salisbury, Remi. 2019. Wrangling with the Black Monster: Young Black mixed-race men and masculinities. British Journal of Sociology 70: 1754-73. [CrossRef]

Kundnani, Arun. 2007. The End of Tolerance: Racism in Twenty-First Century Britain. London: Pluto Press.

Lammy, David. 2017. The Lammy Review: An Independent Review into the Treatment of, and Outcomes for, Black, Asian and Minority Ethnic Individuals in the Criminal Justice System. Available online: https://assets.publishing.service.gov.uk/government/uploads/system/uploads/attachment_data/file/ 643001/lammy-review-final-report.pdf (accessed on 3 February 2020).

Larkins, Cath. 2016. Making the critical links: Strategies for connecting marginalised children's action research with European citizenship. Revista de Asistenţă Socială 2: 11-23.

Larkins, Cath. 2019. Excursions as corporate agents: A critical realist account of children's agency. Childhood 26: 414-29. [CrossRef]

Larkins, Cath, and John Wainwright. 2014. Just Pputting Me on the Right Track': Young People's Perspectives on What Helps Them Stop Offending. Preston: Lancashire.

Larkins, Cath, and John Wainwright. 2020. 'If rich people gave money to poor people': Children's perspectives on reducing offending and implications for social citizenship. Children and Youth Services Review 110: 104702. [CrossRef]

Lashua, Brett. 2015. Mapping the Politics of 'Race', Place and Memory in Liverpool's Popular Music Heritage. In Sites of Popular Music Heritage: Memories, Histories, Places. Edited by Sarah Cohen, Knifton Robert, Leonard Marion and Les Roberts. New York: Routledge, pp. 45-61.

Law, Ian, and June Henfrey. 1981. A History of Race and Racism in Liverpool, 1660-1950. Liverpool: Merseyside Community Relations Council.

Liverpool Black Caucus. 1986. The Racial Politics of Militant in Liverpool: The Black Community's Struggle for Participation in Local Politics 1980-1986. Liverpool: Writing on the Wall Merseyside Area Profile Group and Runnymede Trust.

Malik, Kenan. 1996. The Meaning of Race; Race, History and Culture in Western Society. Basingstoke: MacMillan.

McKeown, Michael, and John Peter Wainwright. 2019. Echoes of Frantz Fanon in the place and space of an alternative black mental health centre. Critical and Radical Social Work. [CrossRef]

McKeown, Mick, Alastair Roy, and Helen Spandler. 2014. 'You'll never walk alone': Supportive social relations in a football and mental health project: You'll Never Walk Alone. International Journal of Mental Health Nursing 24: 360-69. [CrossRef] [PubMed]

McNeill, Fergus, and Shadd Maruna. 2008. Giving up and giving back: desistance, generativity and social work with offenders. In Developments in Social Work with Offenders. Series: Research Highlights in Social Work 48. Edited by Peter Raynor and Gill McIvor. London: Jessica Kingsley Publishers, pp. 224-339.

Meegan, Richard. 2003. Urban regeneration, politics and social cohesion: The Liverpool case. In Reinventing the City?: Liverpool in Comparative Perspective. Edited by Ronaldo Munck. Oxford: Oxford University Press, pp. 53-79.

Merton, Robert. 1972. Insiders and outsiders: A chapter in sociology of knowledge. American Journal of Sociology 78: 9-47. [CrossRef]

Miles, Robert, and Malcolm Brown. 2003. Racism. London: Routledge.

Mistry, Rohinton. 1996. A Fine Balance. London: Faber and Faber. 
Mullen, Jessica, Mark Blake, Jeremy Crook, and Clive Marti. 2014. The Young Review: Improving Outcomes for Young Black and/or Muslim Men in the Criminal Justice System Final Report. Available online: http: //www.youngreview.org.uk/sites/default/files/clinks_young-review_report_dec2014.pdf (accessed on 1 April 2020).

Nayak, Anoop. 2006. After race: Ethnography, race and post-race theory. Ethnic and Racial Studies 29: 411-30. [CrossRef]

Nayak, Suryia, and Rachel Robbins, eds. 2018. Intersectionality in Social Work: Activism and Practice in Context. London: Routledge.

Neely, Brooke, and Michelle Samura. 2011. Social Geographies of race: Connecting race and space. Ethnic and Racial Studies 34: 1933-52. [CrossRef]

Nichols, Naomi. 2017. Technologies of evidence: An institutional ethnography from the standpoints of youths at risk. Critical Social Policy 37: 604-24. [CrossRef]

Obasi, Chijioke. 2014. Negotiating the insider/outsider continua: A black female hearing perspective on research with deaf women and black women. Qualitative Research 14: 61-78. [CrossRef]

Obasi, Chijioke. 2017. Space, Place, Common Wounds and Boundaries: Insider/Outsider Debates in Research with Black Women and Deaf Women. In Handbook of Research Methods in Health Social Sciences. Singapore: Springer.

Omi, Michael, and Howard Winant. 2002. Racial formations. In The Social Construction of Difference and Inequality: Race, Class, Gender and Sexuality. Edited by Tracy E. Ore. New York: McGraw-Hill.

Palmer, Suzella. 2009. The origins and emergence of youth 'gangs' in a British inner-city neighbourhood. Safer Communities 8: 17-26. [CrossRef]

Reason, Peter, and Hilary Bradbury. 2006. Introduction: Inquiry and Participation in Search of a World Worthy of Human Aspiration. In Handbook of Action Research. Edited by Peter Reason and Hilary Bradbury. London: Sage, pp. 1-14.

Sharp, Douglas, and Susie Atherton. 2007. To Serve and Protect?: The Experiences of Policing in the Community of Young People from Black and Other Ethnic Minority Groups. British Journal of Criminology 47: 746-63. [CrossRef]

Singh, Gurnam. 2004. Anti-Racist Social Work, Context and Development: Refracted Through the Experiences of Black Practice Teachers. Unpublished Ph.D. dissertation, University of Warwick, Coventry, UK.

Sivanandan, Ambalavaner. 1985. RAT and the degradation of the black struggle. Race and Class 26: 1-33. [CrossRef] Small, Stephen. 1991. Racialised relations in Liverpool: A contemporary anomaly. Journal of Ethnic and Migration Studies 17: 511-37. [CrossRef]

Solomos, John. 1996. Racism and Society: Sociology for a Changing World. London: Palgrave Macmillan.

Taaffe, Peter, and Tony Mulhearn. 1988. Liverpool: A City That Dared to Fight. London: Fortress.

Taylor, Charlie. 2016. Review of the youth justice system in England and Wales. Available online: https: //www.gov.uk/government/...data/.../youth-justice-review-final-report-print.pdf (accessed on 2 October 2016).

Vathi, Zana, and Kathy Burrell. 2020. The Making and Unmaking of an Urban Diaspora: The role of the physical environment and materialities in belongingness, displacement and mobilisation in Toxteth, Liverpool. Urban Studies. [CrossRef]

Wainwright, John P. 2009. Racism, anti-racist practice and social work: articulating the teaching and learning experiences of Black social workers. Race Ethnicity and Education 12: 495-512. [CrossRef]

Wainwright, John P., and Cath Larkins. 2020. Race, ethnicity, young people and offending: the elephant in the room. Social Identities 26: 128-44. [CrossRef]

Wainwright, John Peter, and Michael McKeown. 2019. Place and race: sanctuary, asylum and community belonging. In Inside Out, Outside In: Transforming Mental Health Practices. Monmouth: PCCS Books, pp. 198-215. ISBN 9781910919491.

Wainwright, John P., Mick McKeown, and Malcolm Kinney. 2019. “In these streets": the saliency of place in an alternative Black mental health resource centre. International Journal of Human Rights in Healthcare 13: 31-44. [CrossRef]

Williams, Patrick, and Becky Clarke. 2016. Dangerous Associations: Joint Enterprise, Gangs and Racism—An Analysis of the Processes of Criminalisation. Available online: https://www.crimeandjustice.org.uk/sites/crimeandjustice. org.uk/files/Dangerous\%20assocations\%20Joint\%20Enterprise\%20gangs\%20and\%20racism.pdf (accessed on 1 December 2019). 
Wilson, David. 2006. Some reflections on researching with young Black people and the youth justice system. Youth Justice 6: 181-93. [CrossRef]

Winant, Howard. 2004. The New Politics of Race: Globalism, Difference, Justice. Minneapolis: University of Minnesota Press.

Wright, Cecile. 2010. Othering difference: Framing identities and representation in black children's schooling in the British context. Irish Educational Studies 29: 305-20. [CrossRef]

Youth Justice Board. 2010. Exploring the Needs of Young Black and Minority Ethnic Offenders and the Provision of Targeted Interventions. Available online: https://assets.publishing.service.gov.uk/government/uploads/ system/uploads/attachment_data/file/354686/yjb-exploring-needs-young-Black-minority-ethnic-offenders. pdf (accessed on 1 February 2020).

Zack-Williams, Tunde. 1997. African diaspora conditioning: The case of Liverpool. Journal of Black Studies 27: 528-42. [CrossRef]

(C) 2020 by the authors. Licensee MDPI, Basel, Switzerland. This article is an open access article distributed under the terms and conditions of the Creative Commons Attribution (CC BY) license (http://creativecommons.org/licenses/by/4.0/). 